QAULAN, Vol. 2, No.1, Juni 2021

Dani Saputra, Jurgen Habermas's Communicative....

\title{
JURGEN HABERMAS'S COMMUNICATIVE PARADIGM AS TRANSFORMATIVE DA'WAH REINFORCEMENT
}

\author{
Dani Saputra \\ Magister Students of Universitas Islam Negeri Sunan Kalijaga Jogjakarta \\ Email: danirumi02@gmail.com
}

\begin{abstract}
Work and communication are two basic human that determine how humans as a species move and live in their world. The reformation begins with two basic human foundations. Jurgen Habermas, a German authoritarian who makes a fairly firm discount with his predecessors, seems to be in his central idea of the fundamental differences between the two dimensional praxis, namely work and communication. But it needs to be seen how communication and rationality of power are exercised, or how one positions in it. In the public space, each individual expresses his or her various thoughts related to the public interest that want to be discussed without coercion. This public space must be free from the intervention of any party, so that each individual can express his or her thoughts freely and openly. That's where a social area free from censorship and dominance. The complexity of people's lives demands a more transformative movement of da'wah activities, in this case communication and transformative da'wah. This process also aims to "pay attention" to the target of da'wah to the weak. As coveted by the Islamic community, that not only focused on homogeneous social status, nor looked at the higher and lower social status, officials and subordinates, rich and poor, and so on. Rather, it sees from the level of laughter of an individual to his Lord. To achieve this, preachers need to emphasize an approach that better respects and respects human dignity and dignity, humanizes people, and uses local cultural approaches and the unstoppable use of information technology as a tool to transform a message.
\end{abstract}

\section{Keywords: Paradigm Communication, Public Space, Transformative Da'wah}

\section{INTRODUCTION}

Public spaces are democratic spaces or public discourse vehicles, where citizens can express their opinions, interests, and needs on a discursive basis. Public spaces must be autonomous, without government intervention, because they are a means of communicating, discussing, arguing and expressing attitudes. In addition, although public space is not a legal institution or organization, it can still be used as a forum where citizens can freely state their arguments against the state or government.

A state can be called sovereign when a state (in legislative, executive and judicial institutions) can be connected discursively with the process of forming aspirations and opinions in public spaces. Its accessible nature to everyone, it is possible to form a community solidarity to fight the market machines or capitalists and political machines. 
QAULAN, Vol. 2, No.1, Juni 2021

Dani Saputra, Jurgen Habermas's Communicative....

The public space referred to here is in keeping with the deliberative democracy it embodied. The word deliberative comes from the Latin word deliberation which means consultation, deliberation or weighing. Democracy can be said to be deliberative if the process of granting a reason or a public policy plan is tested first through public consultation or public space. ${ }^{1}$

Deliberative democracy wants to increase the intensity of citizen participation in the process of forming aspirations and opinions so that the policies and laws produced by the governing party are closer to the expectations of the governing party. This theory does not focus its view on certain rules governing citizens, but rather a procedure that produces those rules. How political decisions are taken and under what conditions are the rules produced in such a way that citizens comply with these regulations. ${ }^{2}$

Based on this, the author considers it important that there is a discourse ethics, which here is a normative for a plurality society that no longer has a single moral authority to address the issue. The ethics of discourse are also capable of creating the free spaces needed in a plurality consisting of different lives, both different. Living well for a group is not necessarily good for other groups. The claim of kindness made by a group should be discussed with the other party. Without it, the reality that emerges is the oppressive goodness of the unstated good.

It is necessary to see how communication and rationality of power are exercised, or how one positions in it. In a public space, each individual expresses his or her various thoughts related to the public interest that want to be discussed without coercion. This public space must be free from the intervention of any party, so that each individual can express his or her thoughts freely and openly. That's where a social area free of censorship and dominance will be gained.

The communicative action here, as Habermas says, is the basic human act of living. The first is the basic action in man's relationship with nature as an object of manipulation. The second is a basic act in human relationships with others as fellow subjects. Human action atowards nature are monologial, while its actions against others are dialogal, because humans interact through symbols used and understood intersubjectively as seen in the use of colloquial languange. ${ }^{3}$

Furthermore, Habermas, as quoted in his book Budi Hardiman, that he held an increasingly sharp distingsi about the two basic actions of man so that it became an act of terrorization. The

1F. Budi Hardiman, Towards a Communicative Society; Society, Politics, and Postmodernism According to Jurgen Habermas (Yogyakarta, Kanisius, 1993), xxi.

${ }^{2} \mathrm{~F}$. Budi Hardiman, Deliberartif Communication; Considering the State of Law and Public Space in Jurgen Habermas's Theory of Discourse (Yogyakarta: Kanisius, 2009), 128.

${ }^{3}$ F. Budi Hardiman, Towards a Communicative Society, 22. 
QAULAN, Vol. 2, No.1, Juni 2021

Dani Saputra, Jurgen Habermas's Communicative....

basic action can be carried out both in the physical or non-social world and in the human social world. ${ }^{4}$ In terms of action actors, the perpetrator of "rational-purpose"actions have an orientation to success. Failure and success of an action are measured by the extent of its success in realizing a goal. To the extent that this action enters the natural world by meeting certain technical rules, it can be called instrumental.

If this action enters the social world, it becomes strategic by meeting the rules for rational selection. Thus, strategic action is a "rational-purposed" action that is categorized into social interactions as well, only in this case the interaction is not genuine. A genuine interaction is an interaction that is done in communicative actions. Communicative actors have an orientation on the achievement of understanding. In this case, success does not become a measure, and this action is not egocentric. The success of this action appears to be the achievement of copy understanding between the two parties communicating 5

Habermas theory is needed to see how the situation of the boundaries between truth and falsehood, reality and design, are increasingly blurred and difficult to distinguish. Among them are, firstly, the existing reality is pseudo reality and the resulting reality of the simulation (simulacra). Second, something that is created and held to shape the image and public opinion, when it is not the real reality (pseudo-event). Third, efforts to produce a social, political and cultural reality that at first glance seems real when in fact it is a fake. Society is then consigned to believe more in illusions resulting from real reality.

While da'wah is an activity to convey and teach and practice the teachings of Islam in daily life. Dichotomically, the process of da'wah is divided into two models, namely oral bil as da'wah with too verbal kalam. And the second is da'wah with an attitude, with a clear practice. Ideally, both should be balanced, but in reality it is not so. The first is developed and acceptable, while the second is still mired in conveying its value.

Other probem, there is a paradigm overlap in the concept of da'wah during this time, either the first model or the second. The tendency to make people as passive objects of da'wah, which must be guided because of the "dirt" and its actions that are far from religious rules. This is what then makes the preacher then act and act as a referee who punishes the people to return to comply with the rules that apply.

${ }^{4}$ Ibid., 27.

${ }^{5}$ F, Budi Hardiman, Kritik Ideologi; menyingkap pertautan pengetahuan dan kepentingan Bersama Jurgen Habermas (Yogyakarta: Kanisius, 2004), 86. 
QAULAN, Vol. 2, No.1, Juni 2021

Dani Saputra, Jurgen Habermas's Communicative....

As Mansour Fakih said, the ongoing da'wah process tends to be oriented there is a concept of bank-style communication. The audience is likened to an empty furnace that needs to be filled; beliefs, moral values, and practices of life to be remembered and used when they need to be. This resulted, so that the preacher became an active subject, while auiden on the contrary, he did not have any right, even to ask questions and statements. Then it becomes commonplace if the audience (people) then identify a pendawkah as the ideal human prototype. This is reinforced by the culture of society that tends to be paternalistic. This kind of relationship model will create a strong and formal benchmarks. So the success and failure of a da'wah is only seen from the frequent preachers preach and not. How many audiences and how few audiences follow it. ${ }^{6}$

According to Kuntowijoyo, there are at least two social transformations carried out by the Prophet, namely the liberation of people (individuals) and the transformation of society (collective). Through the way transformations ${ }^{7}$, Kuntowijoyo examined the concept of ummah as a political regio-unity, as the consequentp $\mathrm{m}$ akmur state, or prosperous society as the concept of normatif which is in the structure of subjective consciousness. These concepts are projections of the muslim community's ideals of the so-called best people in a good country, under God's forgiveness. ${ }^{8}$ This stage and process then positioned the Prophet Muhammad as the most influential person in human civilization. ${ }^{9}$

To further explore the above, then here needs to be formulated a problem, so that then the discussion becomes a systemic narrative. First, how Habermas' communication paradigm describes human beings who influence each other by means of communication. The act of communication is "rational-purposed" which is the basis of human actions in life. Second, how transfromative da'wah sees the development of discourse that is increasingly difficult to dam.

${ }^{6}$ M. Abu Arif Aini, S.Ag, M.Pd,, http://link24share.blogspot.co.id/2017/02/dakwah-transformatifpespektif.html,quoted on November 20, 2020

${ }^{7}$ Kuntowijoyo, Islamic Paradigm: Interpretation for Action(Bandung: Mizan, 1991), 345.

${ }^{8}$ Ibid., 347.

${ }^{9}$ Kuntowijoyo, Introduction to Anthropology (Jakarta: UI Press, 1998), 3. 
QAULAN, Vol. 2, No.1, Juni 2021

Dani Saputra, Jurgen Habermas's Communicative....

\section{JURGEN HABERMAS COMMUNICATION PARADIGM}

Jurgen Habermas was born in Dusseldorf, Germany. He spent time in Bonnand Marburg. Prior to holding a number of positions at the Institute for Social Research, he eventually became professor of philosophy in Frankfurt. He was the leading contemporary representative of the Frankfurt Madzhab. Renowned for its continued focus on issues of nature and communication and selfawareness, and their role as the cause of social action. Habermas sorts out three cognitive interests common to humans: a technical interest in knowing and controlling the world inour world, an interest in being able to understand each other and join in the activities of the same person,and an interest in eliminating distortions in our understanding of ourselves. And it is this last interest that gave birth to the critical sciences. These different interests rest on the path of classical Marxism economic determinism. ${ }^{10} \mathrm{He}$ also stood out in his efforts to develop a foundation for ethics in the concept for ideal conversational situations, a discourse that categorically-imperatives Kant.11

Work and communication are two basic human foundations that determine how humans as a species move and live in their world. The reformation begins with two basic human foundations. Jurgen Habermas, a German preacher who made a fairly firm discount with his predecessors, seemed in his central idea of the fundamental differences to the two praxis, namely work and communication. ${ }^{12}$

First,based on the new concept of praxis, as a reformer, Habermas was able to reinvigorate Marxist thinking concerning two points of the problem, namely the relationship of theory and praxis and historical materialism. Efforts to find theoretical and pragmatic links were pursued through consensus and communication, a path contrary to the idea of Marxism which generally went down the path of conflict to realize its revolutionaries. Efforts to reinvigorate the theory of

10 The metaphor that Marx and Engels used to characterize the relationship between the economic organizing of society, which is the basic structure, and the political, legal and cultural organizing that is the superstructure. The total number of material life production relationships is "a prerequisite for social, political and intellectual life processes in general. How basic structures define superstructures has been an object in many debates, and writers since Engels have increasingly distanced themselves from the reductionist and mechanistic implications set forth in this metaphor, which is to show that the relationships involved in production are not only economic, but also involve political and ideological relationships. The view that causal all power to be circusat in basic_structures and everything in superstructure is nothing more than a epifenomena_sometimes called econometrics. Surprisingly, these problems are similar to thoses that arise in the concept that mental processes are considered the result of physical processes, sho the debate is moved away from the assessment of mental characteristics in order to better understand physical processes, and the end is stuck in physiological descriptions.

${ }^{11}$ Simon Blackburn, Kamus Filsafat (Yogyakarta: Pustaka Pelajar), 381.

${ }^{12} \mathrm{~F}$, Budi Hardiman, Kritik Ideologi; menyingkap pertautan pengetahuan dan kepentingan bersama Jurgen Habermas (Yogyakarta: Kanisius, 2004), 88. 
QAULAN, Vol. 2, No.1, Juni 2021

Dani Saputra, Jurgen Habermas's Communicative....

historical materialism where pursued by incorporating elements of communication, as an anthropological and genetic category of the development of society.

Second, contrary to the new concept of praksis, the communication paradigm seeks to solve the "dead end" that has never been resolved. In this case Habermas's criticism of his predecessors. This is evident in his efforts to reformulate the concept of rationalization. ${ }^{13}$

As is the case with the practical intention of having a target group, so is the paradigm of communication. Habermas' predecessors viewed intellectuals as their target group, which at the same time addressed their theory. However, it is rather difficult to show the target group Habermas communication paradigm. If the theoretical address is the human ratio, of course the target group is the. However, the ratio is not a"group" because the ratio belongs to all groups of people, both in power and controlled. ${ }^{14}$

From his point of view, it is not appropriate for Habermas to be neutral, because to himself the ratio is an impartial ratio, which is a ratio that has emancipatory interests. So even if Habermas doesn't designate a particular group in society as his advice group, that impartial ratio will indicate who should be released. That target group could be anywhere, as far as they are under power and dogmatism. ${ }^{15}$

In this case, Habermas does not prioritize certain social groups, but rather prioritizes the ratio. A theory produced by an impartial ratio is directed at the target group to encourage a process of self-reflection above the interests of the group's members. While this target group realized itself in that theory, the so-called Habermas "enlightenment process" was essentially an emancipatory process of various forms of dogmatism and ideology. ${ }^{16}$

In his article, Labor and Interaction,Habermas argues that Hegel has actually understood communication and work as two things that cannot be reduced to each other. ${ }^{17}$ Hegel actually also understands the Spirit and Ratio in relation to human communication through language. Language has an equivalent meaning to work, as both allow humans to distance from an object. If work allows

13 Ibid, 88-89

14 Ibid, 98

15 Ibid, 102

16 Ibid, 108

${ }^{17}$ A. Giddens, Labour and interaction, dalam J.B Thompson, 149-150. 
QAULAN, Vol. 2, No.1, Juni 2021

Dani Saputra, Jurgen Habermas's Communicative....

humans to distance from nature, Language allows taking distance against the direct perceptions that humans capture. 18

Language is also a medium for self-awareness, in addition to work. In this case that language also relates to rasio or self-awareness. This philosophical distingsi continued to develop Habermas in his theory of two basic human action (theory of action) ${ }^{19}$

In his article, Techlogoly and Science as "Ideology", Habermas further demonstrates that the designation is at the level of empirical action. Regarding what he called "rational-purposeful actions", Habermas said:

"With "rational-purposed" work ir action, I understand instrumental action or rational combined selection of both. Instrumental action is determined by technical rules based on empirical knowledge. In any case, those rules state conditional predictions about observable physic or social events. These predictions can be proven accurate or false. Rational electoral behavior is determined by strategies based on analytical knowledge. The strategies state indirectly the deductions of preference rules (value systems) and decisionmaking procedures: these propositions can be precisely or erroneously deductible. Rational action aims to determine goals under pre-existing conditions. But while instrumental actions govern suitable or unsuitable means according to the criteria of effective mastery of reality, strategic action depends only on the proper evaluation of the possible alternative selection, resulting from calculations added by the values and norms." 20

Regarding communication, which in the article was likened to interaction, he explained:

"By interaction, on the other hand, I mean communicative actions, symbolic interactions. The communicative action is determined by binding consensual norms, which determine reciprocal expectations regarding behavior and which must be understood and known by a least two subjects acting. Social norms are enforced through sanctions. The meaning of these norms is objektified everyday communication. While the validity of technical and startegi rules depends on the validity of proposissi-propositions that are analytically appropriate and empirically correct, the validity of social norms is based only in the intersubjectivity of mutual understanding of the intentions and guaranteed by general knowledge of the obligations. ${ }^{21}$

Habermas also points out that both in "rational-purposed" actions and in communicative actions, behavior that violates the rules will have certain consequences. He continued:

"Violations of a rule have different consequences by type. Unsanored conduct, which violates technical rules or valid strategies, is determined per se to fail in the absence of success; The 'punishment' that occurs, say, is a rejection by reality. Deviant behavior, which

\footnotetext{
18 F, Budi Hardiman, Ideological Criticism, 96.

${ }^{19}$ Ibid, 95

20 J. Habermas, Toward a Rational Society (London: Hinemann 1971), 91-91.

21 Ibid, 92.
} 
QAULAN, Vol. 2, No.1, Juni 2021

Dani Saputra, Jurgen Habermas's Communicative....

violates consensual norms, imposes sanctions related to the rules only externally, i.e. by convention." 22

The above analytical situation model, in habermas further thought phasa, was developed into linguist theory. Because communication is revealed through language, systematically distorted communication can also be analyzed by means of linguistic-analytics. Criticism of ideology as a criticism of knowledge manifests itself in criticism-language. The reasons Habermas himself stated are:

"Today the language problem has replaced the traditional problem of consciousness; transcendental criticism of language replaces transcendental criticism of consciousness."23

With the linguistic theory then called the theory of communicative competence Habermas remained on the path of his original concern, namely to provide a solid epistemological targeting for ideological cryonics. Criticism is understood as criticism-knowledge and knowledge as communicative radio. This theory of communicative competence is a means of recontructing the general pre-conditions for free communication from mastery. ${ }^{24}$

So-called mastery-free communication is genuine communication, a communication that is not ideologically distorted. But where can it be known that a communication is pure and free from ideology? If a consensus can be reached through the emancipatory dialogue, from where do we know the true fault of the consensus? The same question can also be asked on the theory of communication competence. If the theory is a means of creating a general pre-requisite for communication that is free of that ideology, what is the normative grip on this theory?25

\section{TRANSFORMATIVE DA'WAH}

The complexity of the problem mentioned by Habermas above, has something to do in the context of da'wah communication, so the author feels the need to relate and try to use the theory to parse the problem in the process of da'wah. Da'wah activities, these days do get a fairly wide space, either through social media or mass media. However, the massive activity of da'wah was unfortunately "not" or did not have a significant impact on the community. The level of crime, corruption, intolerance, and even hostility to the internal Religion of Islam itself has not decreased (if not to say stagnant).

\footnotetext{
22 Ibid, 93

${ }^{23} \mathrm{~F}$, Budi Hardiman, Kritik Ideologi, 97.

24 J,B, Thinpson, Critical Hermeneutic, 90.

25 F, Budi Hardiman, Kritik Ideologi, 116.
} 
QAULAN, Vol. 2, No.1, Juni 2021

Dani Saputra, Jurgen Habermas's Communicative....

There are problems here, such as the lack of da'wah material delivered to answer ongoing problems. This is what then needs to present a communication paradigm to parse the problem. Considering, the purpose of communication is nothing but to create a change. In contrast, transformative da'wah is just an attempt to convey the essence of Islam itself, how it is necessary to review historicality, and restore the substance of religion by using transformative da'wah.

Transformative da'wah is a model of da'wah that not only relies on verbal methods to convey religious materials to the community, which positions the preacher as the conveyer of religious messages, but is able to internalize religious messages into real life by mentoring the community directly. ${ }^{26}$

In this case it certainly follows the critical communication model offered by Habermas, which supposes the process of passive transformation. This means that both preachers and audiences have the capacity as subjects. Certainly in certain rules. So that the audience receives not only theological content that continues to be repeated in different times and places, without considering the social aspects that are also no less important. The preacher at least tried to see this problem as an evaluation material when re-doing the process of da'wah, how and how far the influence of da'wah to the audience. In this da'wah by using a lot of time.

With this, the process of da'wah is not only aimed at strengthening aspect of community religiosity, but also able to strengthen the social base in order to realize social transformation. With transfromative da'wah, preachers are assumed to have a dual function, namely to conduct activities to disseminate religious material and provide assistance to the community, for example on environmental issues, corruption, women's rights, humanity problems, and interfaith conflicts, as well as other issues that develop.

Based on this function, preachers must have a solid base to act as mediation for social change through empowerment activities, such as advocacy for people's rights by the state. ${ }^{27}$

Etymologically, transformation is born from the word transform which is understood as a change in shape, appearance, and change of format, as well as a change in nature. Or something shape change with consideration of changes in character, conditions, function, nature and others. In this context Adams borders on that social transformation is a complete change, both physical and personality. While the definition of transformation in social terminology is a complete change in

${ }^{26}$ Mustafa Hamidi, Dakwah Transformatif (Jakarta: PP LAKPESDAM NU, 2016), 5.

${ }^{27}$ Abdullah Cholis Hafidz, Ahmad Syaiful Wafa, dkk, Dakwah Transformatif (Jakarta: PP LAKPESDAM NU, 2006), 3. 
QAULAN, Vol. 2, No.1, Juni 2021

Dani Saputra, Jurgen Habermas's Communicative....

terms of form, nature, appearance, character in reciprocity between humans as individuals and humans as a group. Transformation is defined by social change and factors that exist in the process of social change, which includes educational factors, technology, cultural values and social movements. ${ }^{28}$

Society undergoes transformation if awareness arises to enlighten and free itself from dominance, both feudal dominance, and bourgeois domination. Namely by creating an ideal society that is a society without class. According to Karl Marx,this awareness aims to raise due to material pressures and production. In other words, awareness to fight will move the community and its structure. It is this movement that marks a transformation. ${ }^{29}$

In this case, transformation can be interpreted as an alternative model or form of social change that becomes the main goal of any social movement that cannot be separated from development problems. These updates occur because of causes that occur inside and outside. For Muhajir, transformation in sociology and anthropology is defined as a fundamental change to the change in cultural values. Along with it there is a transformation process regarding the adoption process and on other cultures. ${ }^{30}$ If awareness of the similarities in this traditional society is well developed, then social change will occur. This is one important point about the paradigm of communication with transformative da'wah.

The complexity of people's lives demands a more transformative movement of da'wah activities, in this case communication and transformative da'wah. This process also aims to "pay attention" to the sarasan da'wah to the weak. As coveted by the Islamic community, that not only focused on homogeneous social status, nor did it look at higher and lower social status, officials and subordinates, rich and poor, and so on. Rather, it sees from the level of laughter of an individual to his Lord. To achieve this, preachers need to emphasize an approach that better respects and respects human dignity and dignity, humanizes people, and uses local cultural approaches and uses unstoppable information technology as a tool to transform a message. If these things are carried out by the preacher, then in the Muslims will be realized a society that muttaqien. ${ }^{31}$

${ }^{28}$ Ensiklopedia Nasioal Indonesia (Jakarta: PT Cipta Adi Pustaka, 1991), 422.

${ }^{29}$ Kuntowijoyo, Paradigma Islam Interpretasi Untuk Aksi (Bandung: Mizan, 1991), 295.

30 Noeng Muhajir, Islam Ideoogi Transformatif (Jogjakarta: Yayasan Penerbit Pers Suara Muhammadiyah), 48.

${ }^{31}$ Ali Nurdin, Dakwah Transformatif, pendekatan dakwah menuju masyarakat muttaqien, Jurnal Ilmu Dakwah Vol. 8 No.2 Oktober 2003, 32. 
QAULAN, Vol. 2, No.1, Juni 2021

Dani Saputra, Jurgen Habermas's Communicative....

There are at least five indicators required in the transformative da'wah process. First, looking at the material aspects of da'wah, namely seeing meaningful changes, such as the transformation form ubudiah material to material that correaltes with social issues. In this context, preachers are encouraged to innovate the material of da'wah that they want to convey, such as social issues; corruption, bullying, misconduct, and corruption, so that preachers do not only discuss issues of as ukhrawi. The preachers no longer give their material oriented to blame and consider those who are non-Muslims as an enemy. Where the trend that takes place is the preachers give material that is charged with hostility to other religions simply because of differences. Therefore, the content delivered by the preacher must be inclusive, this is the key word of transformative da'wah. ${ }^{32}$

Second, there is a method towards change, from the process of da'wah monologues to dialogue. With this, the delivery of da'wah conducted by the preacher has changed, he no longer uses a monologue approach, but emphasizes the process of dialogue with his worshippers. This will have good consequences, for example the problems that take place in the community will then geta solution from the preacher who has the capacity there. Dakwah monologue that lasts so far emphasizes the process of indoctrination only to the audience, while Islam is not only doing that, but also enlightenment for the people in order to escape the problems faced. ${ }^{33}$

Third, involve institutions that can be invited to cooperate in action. Preachers should use institutions as the basis of the movement so that what they fight for gets stronger power. Awareness that resources are not only owned by individuals should be realized by preachers. The social movements requires the legitimacy of institutions to strengthen their influence over society. Fourth, there is a form of defense against the weak. The preachers are tapped to carry out social efforts for the benefit of the oppressed, especially where he conducts his preaching process. Fifth, the preachers also assisted and organized the community that was experiencing the case and needed outside forces to solve it. Here the role of preacher is needed to internalize the teachings he delivered. ${ }^{34}$

The five things above are the process of da'wah conducted by the preachers in using a transformative approach. The end result is to create preachers who can doo assistance on social problems that are engulfing the community. ${ }^{35}$ In this context, the process of delivering da'wah to

\footnotetext{
32 Mustafa Hamidi, Transformative Da'wah (Jakarta: PP LAKPESDAM NU, 2016), 5.

33 Ibid, 5.

${ }^{34}$ Ibid, 6.

35 Jalaludin Rahmat, Islam Aktual, Refleksi seorang Cendekiawan (Bandung: Mizan 1998), 43.
} 
QAULAN, Vol. 2, No.1, Juni 2021

Dani Saputra, Jurgen Habermas's Communicative....

the community should be based on the value of peace, social piety in accordance with the ideals of the religion itself, in addition to encouraging changes in tolerant and inclusive religious expression.

So it is expected that the preachers have a role to startegis to change the religious view of society that is very easy to get influence from the preacher. It is hoped that the ongoing process will facilitate a comprehensive religious understanding. People as part of the process of da'wah will get a new view of their religion. Furthermore, Islam will be the face where the beginning comes, namely shady, calming and making accommodating changes to the development that occurs in the community.

\section{CONCLUSION}

How does Habermas' communication paradigm in describing human relationships affect each other by means of communication? To answer this, departing from the discussion above, finally the author concluded that Modernism's criticism of Frankfurt Madzab, which in this case is represented by Habermas is echoed by his criticism of the objective paradigm of science that regards human as passive objects. Physical and spiritual activities are calculated mathematically. Whereas this paradigm is barren in praxis and only dwells in the complexity of theory. The absence of emancipation and not lead to liberation. A science only for science and no consideration of value, just focus on development. This results in the lasting of the status quo, thus forgetting the historicality of the idea: forgetting that any theory arose because of its own history, thus emerging new understandings; secularism, socialism, capitalism, and so on. Madzab Frankfurt ends with pessimism, all already subject to total manipulation, instrumental ratios, giving birth to a onedimensional humans. According to Habermas, there was a mistake made, firstly, still acknowledging the subject-object; the master-servant, powerfully-overpowered. Second, accepting objectification, humans in relation to other humans have adopted a similar approach to how to deal with nature. Not to mention the owners of capitalist capitalists form a culture of consumerism so as to blunt the human mind.

Da'wah activities, these days do get a fairly wide space, either through social media or mass media. However, the massive activity of da'wah was unfortunately "not" or did not have a significant impact on the community. The level of crime, corruption, intolerance, and internal hostility of Islam itself has not decreased. There are problems here, such as the lack of da'wah material presented to answer the ongoing problems. This is what then needs to present a communication paradigm to parse the problem. Considering, the purpose of communication is nothing but to create a change. In conjunction with that, transformative da'wah is just an attempt to 
QAULAN, Vol. 2, No.1, Juni 2021

Dani Saputra, Jurgen Habermas's Communicative....

convey the essence of Islam itself, how it is necessary to review historicality, and restore the substance of religion by using transformative da'wah.

This is the end of the processof da'wah conducted by preachers in using transformative approach. The end result is to crate preachers who can do assistance on social problems that are engulfing the community. In this context, the process of delivering da'wah to the community should be based on the value of peace, social piety in accordance with the ideals of the religion itself, in addition to encouraging changes in tolerant and inclusive religious expression.

So it is expected that the preachers have a role to change the religious view of society that is very easy to get influence from the preacher. It is hoped that the ongoing process will facilitate a comprehensive religious understanding. People as part of the process of da'wah will get a new view of their religion. Furthermore, Islam will be the face where it first comes, namely shady, calming and making accommodating changes to the developments that occur in the community.

\section{REFERENCES}

Abdullah Cholis Hafidz, Ahmad Syaiful Wafa, dkk, Dakwah Transformatif, Jakarta: PP LAKPESDAM NU, 2006

Aini, M. Abu Arif, S.Ag, M.Pd, http://link24share.blogspot.co.id/2017/02/dakwah-transformatifpespektif.html, 20 November 2020

Blackburn, Simon, Kamus Filsafat, Pustaka Pelajar: Yogyakarta 2013

Ensiklopedia Nasioal Indonesia, Jakarta: PT Cipta Adi Pustaka, 1991

Giddens, A, Labour and interaction, dalam J.B Thompson

Habermas, J, Toward a Rational Society, London, Hinemann 1971

Hamidi, Mustafa, Dakwah Transformatif, Jakarta: PP LAKPESDAM NU, 2016

Hamidi, Mustafa, Dakwah Transformatif, Jakarta: PP LAKPESDAM NU, 2016

Hardiman, F, Budi, Kritik Ideologi; menyingkap pertautan pengetahuan dan kepentingan Bersama Jurgen Habermas, Yogyakarta, Kanisius, 2004

Hardiman, F. Budi, Komunikasi Deliberartif; Menimbang Negara Hukum dan Ruang Publik Dalam Teori Diskursus Jurgen Habermas, Yogyakarta, Kanisius, 2009

Hardiman, F. Budi, Menuju Masyarakat Komunikatif; Ilmu Masyarakat, Politik, dan Postmodernisme Menurut Jurgen Habermas, Yogyakarta, Kanisius, 1993

Kuntowijoyo, Paradigma Islam: Interpretasi Untuk Aksi, (Bandung, Mizan 1991)

Kuntowijoyo, Pengantar Antropologi, (Jakarta: UI Press, 1998) 
QAULAN, Vol. 2, No.1, Juni 2021

Dani Saputra, Jurgen Habermas's Communicative....

Muhajir, Noeng, Islam Ideoogi Transformatif, Jogjakarta: Yayasan Penerbit Pers Suara Muhammadiyah

Nurdin, Ali, Dakwah Transformatif, pendekatan dakwah menuju masyarakat muttaqien, Jurnal Ilmu Dakwah Vol. 8 No.2 Oktober 2003

Thohir, Umar Faruq. "Pemikiran Mistisisme Annemarie Schimmel." ULUL ALBAB Jurnal Studi Islam 13.2 (2012): 203-218.

Thohir, Umar Faruq. "Tauhîd dan Sikap Tawakkal; dari Passiva Menuju Activa." HUMANISTIKA: Jurnal Keislaman 1.1 (2015): 53-72.

Rahmat, Jalaludin, Islam Aktual, Refleksi seorang Cendekiawan, Bandung, Mizan 1998. 